\title{
ON A SMALL COLLECTION OF SIPHONAPTERA FROM THE ADIRONDACKS, WITH A LIST OF THE SPECIES KNOWN FROM THE STATE OF NEW YORK.
}

\author{
BY DR. KARL JORDAN.
}

\section{(With text-figures 5 to 8 .)}

\section{THE majority of Fleas known from the Atlantic States of North America were collected in Maryland and Virginia at places which are in easy reach} from Washington, D.C., the centre of taxonomic activities in U.S.A. In comparing specimens of the same species from various eastern localities it struck me as peculiar that, in contrast with the Western States, (1) there was no geographical variation discernible in the material examined, and (2) that the number of species was very small. In order to ascertain to some extent as to whether these phenomena were more apparent than real, I seized the opportunity which my attendance at the IV. International Congress of Entomology (Ithaca, August 1928) offered to go for a short collecting trip to the Adirondacks. I selected these mountains in the north of the State of New York, because I could expect to meet there northern elements in the fauna and to find species with a wide southward distribution which might possibly show some geographical modification in this northern district with a severe winter.

Just as the best collecting-ground for a beginner is the collection of an experienced friend, so the easiest way for a biologist of finding a suitable locality is to leave the choice to a friend who knows the ground. Dr. S. A. Bishop, professor at the University of Rochester, made arrangements for me to stay at the Adirondack Lodge of the Lake Placid Club, and, with truly American hospitality, even transported me there in his car. I am most grateful to Dr. Bishop for thus rendering the journey so easy and for introducing me to a place which exactly suited my requirements. I am likewise very much obliged to Mr. H. W. Hicks, secretary of the Lake Placid Club, for the great courtesy of giving me permission to stay in the camp as long as I liked and for assigning to Dr. Bishop and myself a spacious block-house where we could make ourselves comfortable, spread out our collecting paraphernalia and work and sleep undisturbed.

With Dr. Bishop as a guide I soon mastered the geography of the place and, when to my great regret my friend had to return to Rochester, could find my way about the woods, which, however, was not difficult, as the trails are all well marked. Adirondack Lodge being situated in the forest at an altitude of about 1,200 ft., 5 miles from the nearest farm, at a small lake under Mt. MacIntyre, it is an ideal spot for collecting the small mammals which occur in such situations.

The weather continued fine during the end of August and early September, with an occasional rainy day and Mts. Marcy and MacIntyre frequently capped with clouds. The camp was lively with the coming and going of people who hiked in the mountains, earrying a heavy camping outfit like hardy scouts, enduring heat and facing rain, slipping in the black mud of the trails and enjoying 
it all in this glorious wooded country. I did not follow the enthusiastic and energetic hikers who ate up the miles as fast as feet and breath would permit, but strolled about in a more leisurely way, setting traps and becoming acquainted with what there was to see and observe for a lover of nature, only occasionally taking the traps as far as Indian Pass. Alluring as the heights were, I abstained from trapping high up, as I had no outfit for staying with the traps overnight far away from the camp, and did not feel inclined to carry the traps a distance of three or four hours one day and to walk the same distance the next morning with the probable result, the nights being cold, that the mammals caught would be dead and abandoned by the parasites which I wanted. My captures, therefore, were made on the slopes of Mt. Jo and Mt. MacIntyre and round about the lake. I was equipped for trapping Rodents and Insectivora only and did not try to obtain Carnivora and Bats, which were rare anyhow, and it was too late in the year for getting bird fleas from abandoned nests. The collection, therefore, is limited, but it comes nevertheless up to the result I usually have when trapping in a restricted area for a few weeks : round about a dozen species of fleas. The mammal most frequently caught in the little box-trap I use was the Short-tailed Shrew, Blarina brevicauda, from which I obtained no less than 5 different species of fleas, two of them new to science. Brewer's mole, Parascalops breweri, was likewise plentiful. The long-tailed Jumping Mouse, Zapus insignis, did not seem to be very rare on the MacIntyre side of the lake, but yielded only 2 specimens of one species of flea, which, however, as a compensation, turned out to belong to a species hitherto only known from Alberta and British Columbia. The Red Squirrel could be heard everywhere in the woods, and the merry Chipmunk was most numerous in and near the camp. I had especially looked forward to eapturing and examining the Porcupine, as no flea had been recorded from the American species. But I was doomed to disappointment when I made the personal acquaintance of the creature in the woods. There were quantities of ticks and mites on it, but no flea. This negative result agrees with the experience of my friend Dr. Preston Clark, whose guides in Maine have examined for me porcupines as well as their winter-nest without finding a single flea, and we may take it as almost certain that the Canadian Porcupine has no flea of its own. A fact of this kind (provided it is a fact) is of great interest in the study of the history of the mammal and flea population. The Snowshoe Rabbit (or Varying Hare) seemed to be fairly plentiful in the Adirondacks ; I expected to find on it the northern hare flea known to me in several geographical forms from Greenland, Baffinsland, New Brunswick, Idaho, British Columbia and Central Asia; but the few hares obtained had, like the porcupine, only ticks and mites, the absence of fleas probably being accidental. While Brewer's Mole was common, I only trapped one specimen of the Starnosed Mole, on which I found the flea common on moles, shrews and voles; as there was no record of fleas off this host, the find was of some little interest to me.

Though the collection is small, it is nevertheless not unimportant as a contribution to our knowledge of the distribution of the fleas of North America, the discovery of a new species of the North-western genus Catallagia being of special interest. Ceratophyllus quirini was known only from Alberta and British Columbia, Doratopsylla curvata from Iowa and Alberta, and of Ceratophyllus acerbus and Leptosylla catatina only the females were known, the former being 
described from Canada and the latter from the Pennsylvanian Alleghanies. From Boston southward the ordinary Blarina flea is Doratopsylla blarinae Fox 1914 ; as at Adirondack Lodge I got D. curvata instead, it would be interesting to ascertain where in the State of New York the two species meet. The two commonest mammal fleas of the Eastern States, Ceratophyllus leucopus and Ctenophthalmus pseudagyrtes remain the same in the Adirondacks as in Virginia and further south.

\section{LIST OF FLEAS.}

\section{Ceratophyllus caedens durus Jord. 1929.}

3 우 off Sciurus hudsonius.—-In these specimens, as well as in the we have from New Brunswick, the abdominal sternite VII has a deep sinus of variable width and depth, more or less as in figs. $f$ and $g$ of Pl. I of this vol., and I cannot find any difference that holds good between the Eastern specimens ( $\hat{o} \hat{o}$ and 우) and the British Columbia ones, although all the examples from Alberta are different. There may be a Northern connection between the Western and Eastern areas of distribution of $C$. caedens durus.

\section{Ceratophyllus leucopus Baker 1904.}

A series off Peromyscus leucopus, its true host.

\section{Ceratophyllus vison Baker 1904.}

A series off Sciurus hudsonius, its normal host.

One of off Tamias striatus, an accidental occurrence, the Chipmunk being common in many places in the woods where the Red Squirrel abounds at Adirondack Lodge.

\section{Ceratophyllus acerbus Jord. 1925 (text-fig. 5 §̂).}

A series of both sexes off Tamias striatus.—Originally described from a single $q$ obtained by Dr. Gordon Hewitt in Canada, without more precise indication of locality.

A second + was collected off the same host by Dr. Preston Clark's guides at Red River Camp, Aroostock Co., Maine, in August 1927. And there is in U.S. Nat. Mus. a $\delta$ and a $q$ from Chapel Pond, Essex Co., N.Y. The material in collections being so scanty, the present series is most welcome.

$\hat{\jmath}$. Process $\mathrm{P}$ of clasper (fig. 5) broad and short, subtriangular, with the apex rounded off. Exopodite $\mathrm{F}$ three times as long as broad in apical half, angle of anterior margin below middle, from this point to apex the exopodite of nearly even width, with the apex posteriorly rounded, above and below point of strongest curvature of apex a blackish spiniform, more or less pointed, the lower one as a rule a little longer and slightly more bristle-like than the upper spine; a little above middle of posterior margin a long strong bristle. IX st. rod-like, very slightly eurved upwards, very feebly widened distally, ending with a very narrow, pointed, membranous flap which has hardly any trace of hair-like filaments ; below apex of IX. st. a long bristle on each side and more proximally long ventral margin a variable number of minute hairs. 
5. Ceratophyllus quirini Roths. 1905.

One pair off Zapus insignis.___Known from British Columbia and Alberta ; the occurrence in the Adirondacks renders it probable that the species is of wide distribution in Canada.

\section{Ceratophyllus gallinae Schrank 1803.}

One $q$ off Tamias striatus, an accidental occurrence. There were no domestic fowl at the camp ; it is therefore probable that the flea lives there on

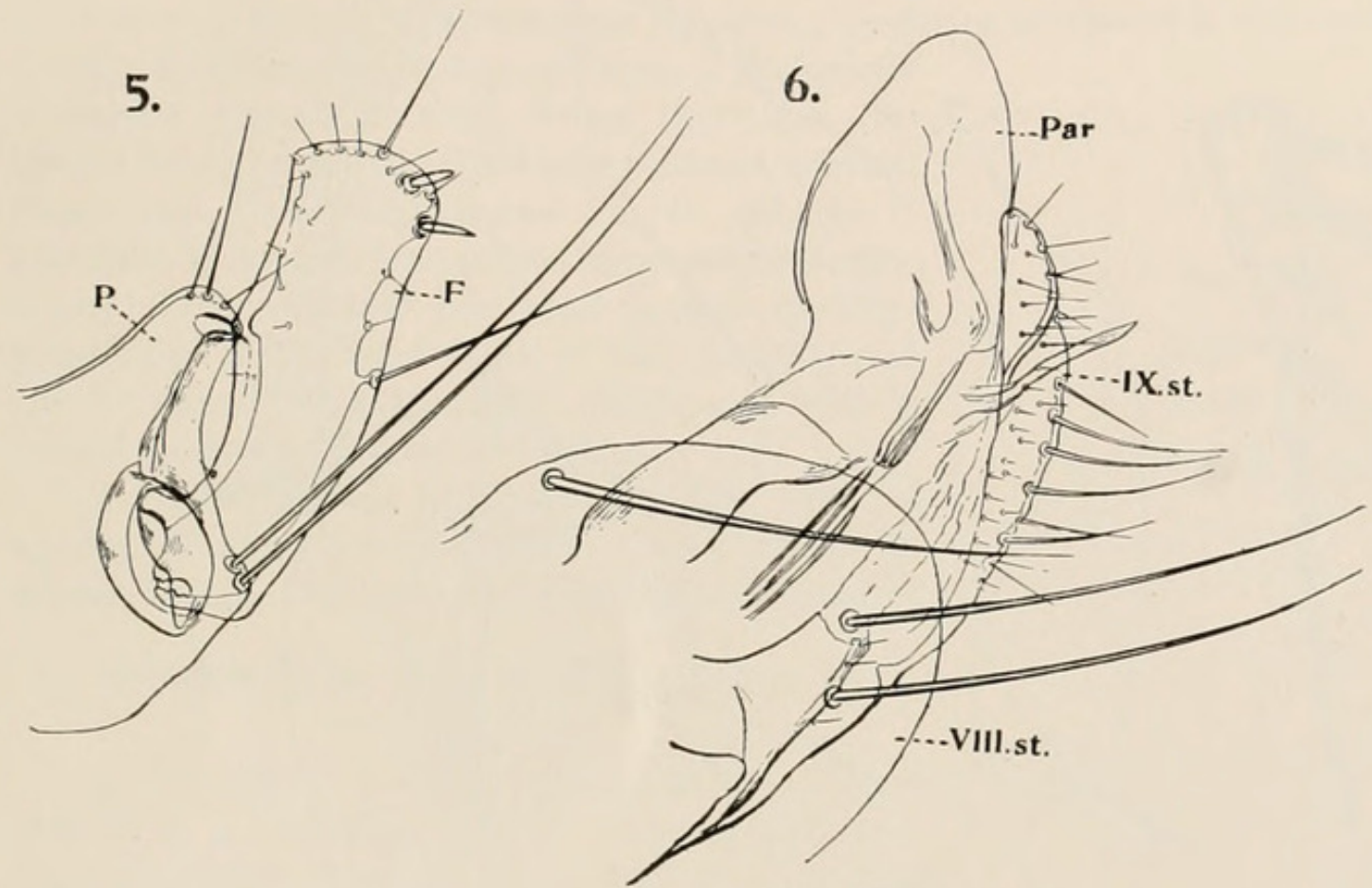

wild birds, the Junco, which was ubiquitous on the ground under the bushes at and near the camp, being the most likely host.

7. Leptopsylla catatina Jord. 1928 (text-fig. 6 ô).

2 ô ô off Parascalops breweri.

2 우 off Blarina brevicauda.

1 off Microtus pennsylvanicus.

Described from one $q$ obtained by me in 1927 at Rolling Rock Club, Ligonier, $\mathrm{Pa}$. The present 3 우 agree very well with the type; two have 4 antepygidial bristles on each side, the third 3 on one side and 4 on the other.

o. On VIII. st. one minute and three very long bristles. Exopodite similar to that of $L$. selenis Roths. 1906, slightly broader, more rounded on anterior side, with 3 long and several small bristles on the posterior side. IX. st. (fig. 6) gradually curved on ventral side, with a ventral series of 5 or 6 longish bristles and numerous small lateral ones; apex not truncate as in L. selenis, but subacuminate. Paramere (Par) subpyriform, with the apex rounded.

\section{Ctenophthalmus pseudagyrtes Baker 1904.}

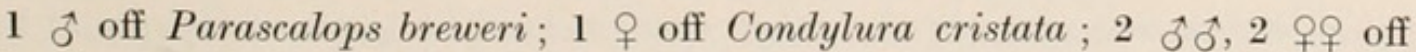
Blarina brevicauda; 1 앙 Rattus norwegicus. 


\section{Doratopsylla curvata Roths. 1915.}

$2 \hat{\jmath} \hat{o}, 1$ \& off Blarina brevicauda.—Only a few specimens are known, from Iowa City and Blackfalls, Alberta.

10. Neopsylla wenmanni Roths. 1904.

$1 \hat{o}$ off ${ }^{\bullet}$ Parascalops breweri; 1 우 off Peromyscus leucopus.—-Widely

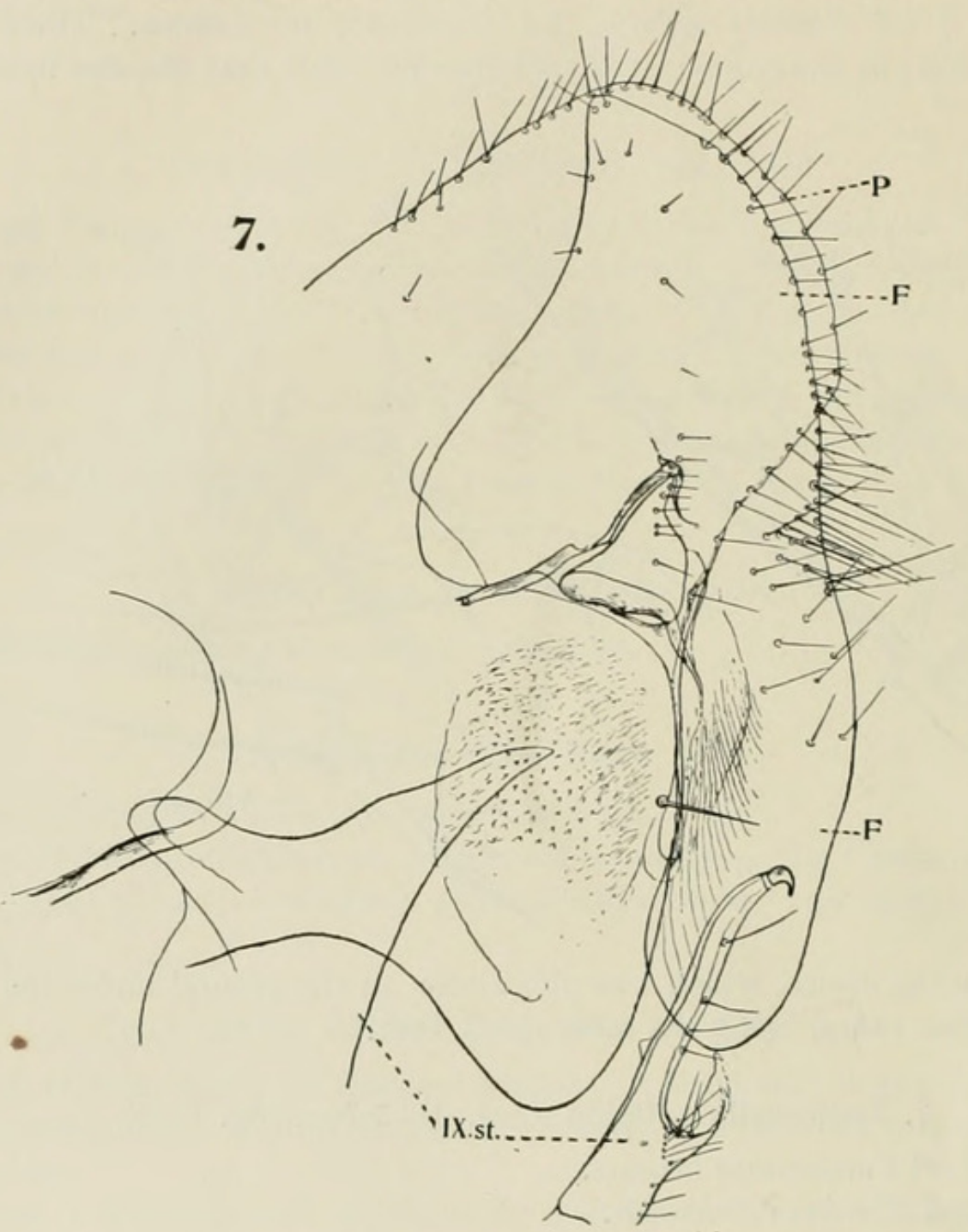

distributed, being in collections from British Columbia, Alberta, New Brunswick, Massachusetts, New York, Maryland and Arizona.

\section{Neopsylla grandis Roths. 1900.}

1 off Tamias striatus.—Neopsylla striata Stewart 1926 is the same species according to the type in the collection at Cornell, Ithaca. Baker, in 1895, identified this flea with Pulex gigas Kirby 1837, in which he was wrong, I think; cf. No. 13. The species is still very rare in collections; I have seen only 5 specimens, inclusive of the above + .

12. Catallagia onaga sp. nov. (text-fig. $7 \hat{\jmath}$ ).

o. Chaetotaxy as in the other species, but the lower antepygidial bristle nearly as long as the middle one, which will no doubt be found to be the case 
also in the . M. Modified segments very different from those of the other species: Manubrium of clasper widened at end, obtuse, slightly turned up. Clasper large, strongly rounded-dilated ventrally; process $\mathrm{P}$ very broad, roundedtruncate, with a series of thin short bristles at the margins as far down as the acetabulum, further down the posterior margin a single, stronger, short bristle. Exopodite $\mathrm{F}$ very peculiar, large, its upper portion subtriangular, with the anterior margin incurved and the apex pointed, this triangle extended down into a long broad nose, which, measured from the middle of the acetabulum, is about as long as the triangular portion and of nearly even width, being onethird as wide as long, with the apex rounded ; posterior margin of $\mathrm{F}$ with a row of thin short bristles similar to those of $\mathrm{P}$, longest on upper portion of nose, where there are also lateral bristles; lower half of nose without bristles. Upper end of vertical arm of IX. st. (ef. fig. 7) extended backwards into a sharply pointed triangle; ventral arm abruptly narrowed beyond middle; proximally of the sinus a row of thin bristles and on the narrow apical portion, which ends with a curved claw, a row of 4 or 5 bristles.

2 ô 0 off Blarina brevicauda.-The other 4 species of the genus are from Queen Charlotte Island, British Columbia, Alberta and California.

\section{Hystrichopsylla gigas tahavuana subsp. nov.} (text-fig. $8 \hat{\sigma}$ ).

๙ิำ. Genal comb with 5 spines; pronotal comb with 30 in 0 and 31 or 32 in . . In front of the two rows of bristles of pronotum no additional bristles

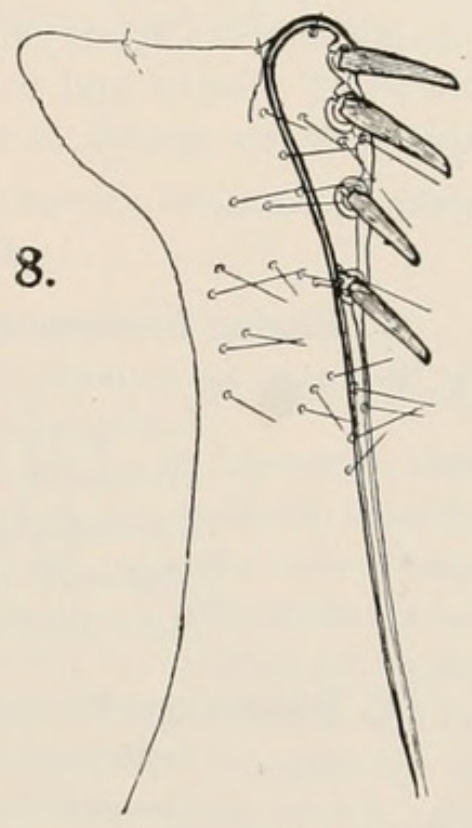
or only one; on mesopleura 28 to 33 bristles and on metepimerum 16 , more rarely 15. Apical spines of abdominal tergites (those of right side in brackets) : on II 5 to 7 (7), III 4 (4), IV 1 or 2 (2). In o two, in of three rows of bristles; on tergites III to VII, with a few additional dorsal bristles representing another row. On outside of mid-and hindfemora a number of lateral bristles at base and again at apex, none in between. Hindtibia, on outside, apart from ventral marginal ones, with 25 or fewer lateral bristles; at dorsal margin 8 notches inclusive of apical one. Longest apical bristle of hindtarsal segment II reaching to apical of III in ㅇ, shorter in $\hat{\sigma}$.

Modified Segments.__ $\hat{\sigma}$ : About middle of elasper an oblique row of 3 long bristles, in front of them 4 to 6 much smaller ones and a few marginal hairs ; near and at posterior margin from 4 to 6 bristles, of which the two upper ones are moderately large. Ventral arm of IX. st. characteristic: with 4 spines each side and the apex enlarged upwards on (each side) into a compressed cone which leans slightly distad._- + VII. st. with a row of 16 or 17 bristles, in front of which there are from 32 to 45 bristles, on the two sides together. The bristles on VIII. t. are one long and 7 to 11 short below stigma, further down 14 to 20 , of which 6 to 8 long, two of the long ones subapical; on inside 10 or 11, some of them very small. At apex of stylet one long bristle.

Length: of $4.0 \mathrm{~mm}$.; $q 4.8$ to $5.5 \mathrm{~mm}$, - Hindfemur: ô $0.8 \mathrm{~mm}$.; 우 0.85 to $0.93 \mathrm{~mm}$. 
One pair off Blarina brevicauda, and one $q$ off Microtus pennsylvanicus.

The flea described and figured by Kirby in Richardson, Fauna BorealiAmericana IV, p. 318, Pl. VI. fig. 9 (1837) as Pulex gigas is a Hystrichopsylla; the dark colouring of the lower portion of the head of the figure corresponds to the genal comb, being well separated from the antennal groove, as is the comb. This little detail in the figure speaks against Neopsylla grandis being the species the figure represents. The two specimens on which Kirby based the name were obtained at $65^{\circ} \mathrm{N}$. Lat., which means, according to the narrative of the Franklin expeditions, the Mackenzie River district south of Great Bear Lake. It is therefore highly probable that Pulex gigas is the same flea as Hystrichopsylla dippiei Roths. 1900 from Calgary, Alberta. However, before establishing the synonymy, it would be advisable to wait for material from the North of Alberta and to treat $H$. dippiei and $H$. gigas for the present as subspecies of one species, of which the name would be $H$. gigas.

\section{Lis T OF MAMALS.}

1. Blarina brevicauda Say 1823. Numerous specimens, frequently caught in the traps set in mole runs.
Leptopsylla catatina, 2 우우.
Ctenophthalmus pseudagyrtes, 2 oิ ô, 2 웅.
Doratopsylla curvata, 2 oิ ô, 1 ㅇ.
Catallagia onaga, 2 ઠิ ठิ.
Hystrichopsylla gigas tahavuana, $1 \hat{\delta}, 1$ 우

2. Parascalops breweri Bachm. 1842. Common in the woods.

Leptopsylla catatina, 2 ô.

Ctenophthalmus pseudagyrtes, 1 ô.

Neopsylla wenmanni, 1 ô.

3. Condylura cristata L. 1758. One specimen, a short distance from camp on the trail to Indian Pass.

Ctenophthalmus pseudagyrtes, 1 우.

4. Rattus norwegicus Erxl. 1777. Near the lake.

Ctenophthalmus pseudagyrtes, 1 ㅇ.

5. Peromyscus leucopus Rafin. 1818. In and near camp, not common.

Ceratophyllus leucopus, 4 ô ô, 14 웅.

Neopsylla wenmanni, 1 ㅇ.

6. Zapus insignis Mill. 1891. Lake shore in a damp place overgrown with rank grass and bushes, 7 specimens, most of them caught alive in box-trap; only 2 fleas on them.

Ceratophyllus quirini, 1 ô, 1 ㅇ.

7. Zapus hudsonius Zimm. 1780. One specimen together with Z. insignis. No flea.

8. Microtus pennsylvanicus Ord. 1815. Only one specimen.

Hystrichopsylla gigas tahavuana, 1 ㅇ․ 
9. Sciurus hudsonius Erxl. 1777. Numerous.

Ceratophyllus caedens durus, 3 우․

Ceratophyllus vison, a series, common on this host.

10. Tamias striatus L. 1758. Many were caught alive, and these were practically the only ones from which fleas were obtained.

Ceratophyllus acerbus, 8 ธิ హิ, 11 웅.

Ceratophyllus vison, 1 s.

Ceratophyllus gallinae, 1 ㅇ.

Neopsylla grandis, 1 ㅇ.

11. Lepus americanus Erxl. 1777. Two specimens examined, one alive, the other dead in a trap.

No flea.

12. Erethizon dorsatus L. 1758. One large specimen, examined immediately after death.

No flea.

III. The Fleas Known from the State of New York.

In The List of the Insects of New York, edited by M. D. Leonard (1928), M. A. Stewart has enumerated (pp. 868, 869) 26 species of fleas with the localities where they have been found in the State of New York, a useful compilation, and the first of its kind in U.S.A. Two western species, Ceratophyllus acutus and $C$. niger, were doubtless included in the list by error, in consequence either of wrong locality labels or of erroneous identification. Three species of Ctenophthalmus are mentioned; but the genus is represented in America by one species only. The Ctenophthalmus gigas Kirby is probably meant for Ct. gigas, Baker nec Kirby, which is a Neopsylla and the same as Neopsylla striata Stew. of the list. Ctenophthalmus wenmanni also is a Neopsylla, N. similis Chapin of the list being the same species. These corrections reduce the number of species to 22 . We can add 9 more (marked with $*$ in the list). This total of 31 represents presumably three-fifths of the species actually existing in the State of New York. The discovery of the western genus Catallagia in the Adirondacks renders it probable that several other western genera will be found in the northern districts of New York. Of the known species the following may be expected to occur in the State:

Hoplopsyllus glacialis lynx Baker 1904; on Snowshoe Rabbit (Varying Hare, Lepus americanus) ; nearest locality : Maine.

Ceratophyllus diffinis Jord. 1925; in nests of various birds; evidently common in New England. Nesting-boxes are most useful for obtaining bird fleas.

Ceratophyllus idius J. \& R. 1920 ; as previous species.

Ceratophyllus garei Roths. ; especially in nests on the ground.

Ceratophyllus gallinulae perpinnatus Baker 1904; only known from Western States, but must be expected to occur also in the Eastern States, on various birds.

Ceratophyllus immitis Jord. 1929 ; on Lemming. I did not succeed in my search for the Lemming which occurs in the Adirondacks.

Odontopsyllus multispinosus Baker 1904; in nest of Cottontail Rabbit. 
Neopsylla faceta J. \& R. 1915 ; on Sciurus hudsonius; only a pair known, from Wilbraham, Mass.

Nearctopsylla hygini Roths. 1904; off Mustela and Putorius ; a subspecies known from New Brunswick. Maine.

Stenoponia americana Baker 1899 ; on mice and voles; nearest place:

Nycteridopsylla chapini Jord. 1929; on Eptesicus fuscus, Large Brown Bat, which is common in southern New York.

Fleas off other Carnivora than those mentioned above, and off shrews, voles and sea-birds may bring the number up to 50. A species of Trichopsylla should occur on the Bear.

1. Echidnophaga gallinaceus Westw. 1875; an introduced Old World tropical and subtropical species; New York City ; on rats. States.

2. Pulex irritans L. 1758 ; comparatively rare in the North-eastern

3. Xenopsylla cheopis Roths. 1903; introduced on ships' rats ; an Old World tropical species.

4. Ctenocephalus canis Curtis 1826; Schenectady and New York City ; on rats, but may be expected to occur on dogs and cats.

5. Ctenocephalus felis Bouché 1835; Ithaca, on eat; evidently not so common as in Europe.

6. Cediopsylla simplex Baker 1895; Ithaca, and Lyons Lake, Rensselaer Co. (Schoonmaker); on Cottontail Rabbit. This is a flea of the nest rather than of the rabbit itself. The European Spilopsyllus cuniculi Dale 1878, on the contrary, attaches itself to the rabbit, sometimes forming a dense crust on the ears.

7. Trichopsylla lotoris Stew. 1926; Olcott; on Procyon lotor lotor. The original pair is all that is known of this interesting species.

8. Ceratophyllus pseudarctomys Baker 1904; Newport, Herkimer Co., and Ithaca ; on Woodchuck and Flying Squirrel.

9. Ceratophyllus wickhami Baker 1895; probably everywhere on Grey Squirrel, also on other squirrels and accidentally on other mammals ; recorded from Ithaca and Halsey Valley.

*10. Ceratophyllus caedens durus Jord. 1929; Adirondack Lodge, Essex Co. ; on Sciurus hudsonius loquax.

11. Ceratophyllus leucopus Baker 1895; probably everywhere on Peromyscus leucopus; Peterboro, Adirondack Lodge and Mt. Kisco.

12. Ceratophyllus arctomys Baker 1904; perhaps everywhere on Woodchuck; accidentally on other mammals; recorded from Peterboro, McLean, Keeseville, Ithaca and Stamford; in N.Y. State Museum, Albany, a + off Odocoileus virginianus from Indian Lake, Hamilton.

*13. Ceratophyllus asio Baker 1904 ; Ithaca ; on " field mice."

*14. Ceratophyllus acerbus Jord. 1925; Chapel Pond and Adirondack Lodge, Essex Co. ; on Tamias striatus.

*15. Ceratophyllus quirini Roths. 1905; Adirondack Lodge; on Zapus insignis.

16. Ceratophyllus vison Baker 1904; Ithaca, Peterboro and Adirondack Lodge; on Sciurus hudsonius loquax, accidentally on Tamias striatus and Putorius, 
17. Ceratophyllus fasciatus Bose 1801; Ithaca; on rat and Putorius noveboracensis; a European species.

18. Ceratophyllus gallinae Schrank 1803 ; Perry, Barker, Adirondack Lodge and Mt. Kisco; in nests of Passer domesticus, in henhouses and, no doubt as in Mass., in nests of various other birds ; accidentally on Tamias striatus.

19. Ceratophyllus riparius J. \& R. 1920 ; Ithaca and Olcott; in nests of Riparia riparia and Ceryle alcyon.

20. Leptopsylla hesperomys Baker 1904 ; Ithaca and Alpine ; on Peromyscus leucopus, and accidentally in vacated kingfisher's nest.

21. Leptopsylla segnis Schoenh. 1816 (=musculi Dugès 1832) ; eosmopolitan, New York City; on rats.

*22. Leptopsylla catatina Jord. 1928; Adirondack Lodge ; on Blarina brevicauda, Parascalops breweri and Microtus pennsylvanicus.

23. Ctenophthalmus pseudagyrtes Baker 1904; Selkirk, Alpine, Ithaca, Adirondack Lodge, Mt. Kisko, Bronxville and Long Lake; on shrews, moles and mice, also obtained off Fiber zibethicus, Rattus norwegicus, Tamias striatus, Sciurus hudsonius loquax; a very common species.

*24. Doratopsylla curvata Roths. 1915; Adirondack Lodge; on Blarina brevicauda.

*25. Doratopsylla blarinae Fox 1914 ; Mt. Kisko ; on Blarina brevicauda.

26. Neopsylla wenmanni Roths. 1904 (=similis Chapm.); Ithaca and Adirondack Lodge ; on Peromyscus leucopus and Parascalops breweri.

27. Neopsylla testor Roths. 1915 ; Lansingburg ; from a nest (of mouse ?) ; only one pair known.

28. Neopsylla grandis Roths. $1900(=N$. striata Stew. $=N$. gigas Kirby, Baker, error of identification); Ithaca and Adirondack Lodge; on Tamias striatus, accidentally on Sciurus hudsonius loquax.

*29. Catallagia onaga Jord. 1919; Adirondack Lodge ; on Blarina brevicauda.

*30. Hystrichopsylla gigas tahavuana Jord. 1929; Adirondack Lodge ; on Blarina brevicauda and Microtus pennsylvanicus.

31. Myodopsylla insignis Roths. 1903; Homer and Ithaca; on Myotis lucifugus and M. subulatus. 


\section{$2 \mathrm{BHL}$ Biodiversity Heritage Library}

Jordan, Karl. 1929. "On a small collection of Siphonaptera from the Adirondacks, with a list of the species known from the State of New York." Novitates zoologicae : a journal of zoology in connection with the Tring Museum 35, 168-177. https://doi.org/10.5962/bhl.part.10824.

View This Item Online: https://www.biodiversitylibrary.org/item/22617

DOI: https://doi.org/10.5962/bhl.part.10824

Permalink: https://www.biodiversitylibrary.org/partpdf/10824

\section{Holding Institution}

Natural History Museum Library, London

\section{Sponsored by}

Natural History Museum Library, London

\section{Copyright \& Reuse}

Copyright Status: In copyright. Digitized with the permission of the rights holder.

Rights Holder: The Trustees of the Natural History Museum, London

License: http://creativecommons.org/licenses/by-nc-sa/4.0/

Rights: http://biodiversitylibrary.org/permissions

This document was created from content at the Biodiversity Heritage Library, the world's largest open access digital library for biodiversity literature and archives. Visit BHL at https://www.biodiversitylibrary.org. 